\title{
The experienced newcomer - The (trans)forming of professional teacher identity in a new landscape of practices
}

Helena Colliander

The self-archived postprint version of this journal article is available at Linköping University Institutional Repository (DiVA):

http:// urn.kb.se/ resolve?urn=urn:nbn:se:liu:diva- 144138

N.B.: When citing this work, cite the original publication.

Colliander, H., (2018), The experienced newcomer - The (trans)forming of professional teacher identity in a new landscape of practices, Teaching and Teacher Education, 69, 168-176.

https:// doi.org/ 10.1016/j.tate.2017.10.012

Original publication available at:

https:// doi.org/ 10.1016/j.tate.2017.10.012

Copyright: Elsevier

http:// www.elsevier.com/

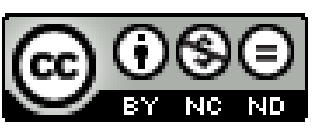


in a new landscape of practices

\section{Introduction}

Extensive migration is part of today's world. In recent years, many countries have received an increased number of refugees and immigrants. Thus, there is a great demand for teachers of a second language, and this also applies to the adult education sector. This study focuses on how professional teacher identity is formed when experienced teachers begin to work in the sector of second language education for adults. More precisely, it deals with how they encounter the teaching practice of Literacy Education and Second Language Learning for Adults (LESLLA). In the Swedish context, where this study is located, LESLLA teaching is part of the educational system of Swedish for Immigrants (SFI). There is study track 1, which is designed for people with no or little previous education. This track has a slow rate of study. It consists of the A and B courses, which have the development of the Swedish language as a general goal, although instruction in initial literacy is given too, either in parallel or included in the language courses. The school can also choose to give literacy instruction in the students' mother tongue as well as in Swedish (The Swedish National Agency for Education, 2012).

In Sweden, new LESLLA teachers are often accustomed to teaching other groups of learners. Even though only $35 \%$ of all SFI teachers are formally qualified as SFI teachers, $70 \%$ of them have a teaching degree (The Swedish National Agency of Education, 2017). Still, LESLLA teaching is a new and challenging field to them. Unlike their students, the teachers, generally, have not experienced what it means to learn print literacy as an adult and there is often a lack of a mutual, oral language in the communication between the teacher and the learners (Bigelow \& Vinogradov, 2011). In her outline of a LESLLA teacher knowledge base, Vinogradov (2013) points out that LESLLA teachers are seldom used to teaching initial literacy and have not been trained in how to do it. That is not always the case in the Swedish context, where a number of SFI teachers have a background as teachers of the lower level of primary school, but like in other contexts (see Vinogradov, 2013), the teachers will often be little used to teaching literacy in L2 and/or to teaching adult learners.

Another challenge is that, since there is a lack of material adapted to the learners' different needs as emergent readers and resourceful adults, many LESLLA teachers have to adjust the teaching material themselves (Vinogradov, 2013, p. 20). Additionally, LESLLA teaching may include meeting learning needs and social needs that are not prescribed in the curriculum. The refugee and immigrant experience of the students, for example, means that the teachers often come to act as mentors or counsellors Magro, 2008, p. 30). Together, these issues imply that the practice of LESLLA teaching, both in Sweden and elsewhere, is different from teaching in primary and secondary school and in other types of adult education.

Previous research illustrates how professional identity is formed by an interplay of different spheres of life, including those outside work and education, and that some of these spheres play a bigger part depending on the time and situation (Nyström, 2009, p. 65). Moreover, a worker can be linked to many professional communities, and the importance of these differs (Hökkä, Rasku-Puttonen, \& Eteläpelto, 2008, p. 60). Thus, professional identity formation is a complex process and this study sets out to explore that of the new LESLLA teacher. Of primary interest to this enquiry is how the professionally identity is formed in the encounter with the new work practices. In turn, this is something which can inform teacher's professional identity in general.

\subsection{Teachers' Professional Identity Formation}

Teachers' professional identity has become a separate field of research and the concept of it has been interpreted in many different ways (Beijaard, Meijer, \& Verloop, 2004, p. 107). 
in a new landscape of practices

Some common features are that it is regarded as something that develops over time and is a matter of contextual as well as individual factors (Beauchamp \& Thomas, 2009, p. 177). The social features of teachers' identity are seen in how teacher development often evolves through teachers' interactions in schools and other communities enabled through conditions such as school culture and policy directives (Avalos, 2011, p. 12). At the same time, teachers actively use their previously acquired identities to learn, review and adjust to the classroom and the general school conditions. Buchanan (2015) shows how teachers draw on their preexisting professional identities to interpret new norms and respond to them by their actions. In this process, the teacher's agency is central. Moreover, Widin, Yasukawa \& Chodkiewicz (2012) draw on Bourdieu to illustrate how the professional teacher identity of experienced teachers, apart from being related to material and non-material conditions, has to do with one's habitus - the tacit and biographically rooted dispositions one uses to orient oneself in a certain field. Depending on the habitus, the teachers may find it more or less easy to acculturate to new circumstances. In her study of language teachers, Rappel $(2015$, p. 324) points out that if teachers are to be able to combine their personal background with organisational and institutional agendas and objectives, it is essential that the work place practices are secure and stable. There must be an authentic communication based on trust in others and belief in oneself. Along the same lines, a study on LESLLA teacher development emphasizes that the opportunities to learn are structured in more or less effective ways. Through collaborative approaches, such as peer observations, study circles and lesson studies, which are easily accessible, the teachers can produce self-directed and school-based knowledge, and can overcome feelings of isolation (Farrelly, 2012, pp. 4-5)

Studies on teacher identity also focus on periods throughout a teachers' career that are particularly critical for identity formation. One of these is when a new teacher begins to teach (Avalos, 2011, p. 11). Another is in a reform context (Vähäsantanen \& Billett, 2008; Vähäsantanen \& Eteläpelto, 2009), for example in the shift from traditional pedagogy to liberal pedagogy (Liu \& $\mathrm{Xu}, 2013$ ) or when new technologies are introduced (Shelley, Murphy, \& White, 2013)

Furthermore, Widin et al. (2012, pp. 23-24) reveal how experienced teachers continue to shape and reshape their teaching practice. Research on adult educators in general, however, shows a difference in focus between experienced and less experienced adult educators. The former tends to concentrate more on the relations with the learners and the educational context, while the latter focus on the subject and the teaching methods (Andersson, Köpsén, Larson, Milana, 2013, pp. 111-112). Yet another study sees how the organisational structure of the work place influences its educators. It shows that they identified with their own subject matter and the teaching of it (Hökkä et al., 2008 p. 60).

\subsection{Aims and Questions}

Even though the research on teacher identity formation covers many areas, there has been less focus on how teachers transfer from one teaching practice to another, particularly when it comes to LESLLA teaching. Since identity is considered an important component of teacher development (Beauchamp \& Thomas, 2009, p.175), this study seeks to contribute to narrowing this gap in knowledge. The element of identity can provide knowledge for teacher educators and shed light on new teachers' learning (Beauchamp \& Thomas, 2009, p. 186). Also, it is useful for understanding how teachers learn when transferring to a new teaching practice.

The aim is to explore how the professional identity of already experienced teachers is formed when they begin to work in the LESLLA field of practice. Taking the perspectives of the teachers, the study seeks to answer following questions: 
THE EXPERIENCED NEWCOMER: the (trans)forming of professional teacher identity

in a new landscape of practices

- How do the teachers present themselves when encountering new professional practices?

- What opportunities for learning afforded by the work place communities are brought up by the teachers?

- How do the teachers respond to these learning opportunities?

\section{Theoretical Framework}

In this study, learning is viewed as a process which involves the whole person and the practices that $\mathrm{s} / \mathrm{he}$ is part of. Another point of departure is that there is interdependence between the social context and the individual agency in this process.

\subsection{Professional Identity Formation, Participatory Practice and Negotiation}

The study applies a perspective on professional identity as the core of the learning process (Lave \& Wenger, 1991). As Handley, Sturdy, Fincham and Clark (2006, p. 644) state: "Learning is not simply about developing one's knowledge and practice, it also involves a process of understanding who we are and in which communities of practice we belong and are accepted." Learning in such a holistic sense evolves through participation together with old-timers - people who have participated longer in the community. In that way, the newcomers become familiar with the functions, tasks and activities of the practice (Lave \& Wenger, 1991). They come to understand and engage with the underlying values of the practice, the explicit and implicit artefacts, and the embedded relations (Handley et al., 2006, p. 645). Such a participatory perspective, expressed in terms of a Community of Practice, has often been used for understanding workplace learning. It offers a way to see how professional identity is formed (Eteläpelto, 2008, pp 234-237).

One of many criticisms of a situated learning perspective is its lack of focus on the individual. Instead of viewing identity formation as something completely social, it is stated that individual agency also plays a part in this process (Billett, 2006; Handley et al, 2006, p. 642). The agency, which includes the ability to make choices and act according to them, is linked to personal goals (Beijaard, Meijer, \& Verloop, 2004, p. 123). It is about the actions people take and how these actions are believed to be in line with their construction of identity (Buchanan, 2015, p. 704). The individual agency becomes even more significant when considering that newcomers to a workplace are not blank pages. They bring knowledge, skills and understanding, which are used both directly in work assignments and indirectly to develop new knowledge and skills. Such prior abilities have structural features, and need to be recognised and deployed in the new context. They cannot simply be transferred (Hodkinson et al., 2004, p. 11). It is too simple to claim that newcomers bring skills and knowledge with them to a new location. Rather, the prior learning has formed the professional identity of the person arriving at the new practice (Fuller, Hodkinson, Hodkinson, \& Unwin, 2005, p. 66).

Essential to situating prior abilities and adjusting to this new work are the actions and attitudes of a teacher's employer and her co-workers. These relationships can either support or hinder her growth in learning and integrating new teaching practices (Hodkinson et al., 2004, p. 22). To better illustrate the relationship between the social context and individual agency, Billett (2004, p. 109) uses the term participatory practices. The notion holds that there is an interdependence between what the workplace can offer in terms of guidance and activities, and the individual participation. Participatory practice is about the opportunities for participation that are afforded in the community and how individuals, depending on their agency, choose to respond to these. Their personal histories, which are uniquely and socially formed by their memberships of different communities, produce identity and influence how the social world is understood and engaged with. Critical for both participation and identity 
formation are the individual teachers' negotiations, which include reflections on the link between the social context and their own experiences, values and professional orientations. By deploying personal strategies to cope with changes, teachers exercise their agency and negotiate their own change (Vähäsantanen \& Billett, 2008).

To understand the relation between the teachers' memberships of different but related professional communities, the concept of landscapes of practices is applied. The notion refers to a body of knowledge "consisting of a complex system of communities of practice and the boundaries between them" (Wenger-Trayner \& Wenger-Trayner, 2015, p. 13). A professional occupation is constituted by such a landscape. Learning evolves when workers journey through it, but not all of the practices included in the landscape have the same significance. They may be more engaged in or identify more strongly with particular ones. A practice may also contribute to identity formation even if they are not personally participating in it. Members of a certain profession can, for instance, by imagination, identify with other members of their profession. This helps them to orient and locate themselves in the world (Wenger-Trayner \& Wenger-Trayner, 2015).

In this study, the LESLLA teachers' identity formation is understood both from their participation in LESLLA working communities and from how they negotiate their professional identity from personal experiences in former communities.

\section{Methodology}

\subsection{The Research Context}

The SFI is an umbrella in which different providers - public, private and civil agencies - offer education. The municipalities have the overall responsibility. Even if there is one joint national curriculum for all SFI schools, there is, depending on the responsible authorities, diversity in how the education is organised. Firstly, the schools have to follow possible political outlines at the municipality level and, secondly, they may have their own vision. Conditions and pedagogical ideals are likely to vary, not only because of the local school context, but also depending on which type of educational system the schools use. Most LESLLA teachers are SFI teachers, but in some cases, there are mother tongue teachers as well. Both groups teach Swedish, but teachers of the latter type do it with the students' mother tongue as a tool.

\subsection{Research Participants and Methods}

Nine teachers currently or previously involved in LESLLA teaching participated in the study. The eight women and the one man (Geedi) worked either in a school run by the municipality or a folk high school. ${ }^{1}$ Six of the respondents currently worked as SFI teachers and three as mother tongue teachers. Even though there are many more SFI teachers than mother tongue teachers both groups deal with LESLLA learners and are therefore represented in the sampling. Another criterion for the selection of teachers was that they had to have experience of teaching other types of learners before they began to work with LESLLA. Some information on the teachers' professional background is given in Table 1 below:

Table 1 Professional background of the teachers

\footnotetext{
${ }^{1}$ A folk high school is a type of civic education for adults.
} 
THE EXPERIENCED NEWCOMER: the (trans)forming of professional teacher identity

in a new landscape of practices

\begin{tabular}{|c|c|c|c|c|}
\hline Name & $\begin{array}{l}\text { Type of } \\
\text { teacher } \\
\text { employm } \\
\text { ent }\end{array}$ & $\begin{array}{l}\text { Educational } \\
\text { background when } \\
\text { beginning the LESLLA } \\
\text { career }\end{array}$ & $\begin{array}{l}\text { Previous professional } \\
\text { experience mentioned by } \\
\text { the teachers }\end{array}$ & $\begin{array}{l}\text { Period } \\
\text { working } \\
\text { as a } \\
\text { LESLLA } \\
\text { teacher* }\end{array}$ \\
\hline Agnes & $\begin{array}{l}\text { SFI } \\
\text { teacher }\end{array}$ & $\begin{array}{l}\text { Recreation instructor } \\
\text { Primary school teacher } \\
\text { degree } \\
\text { Swedish as a second } \\
\text { language }\end{array}$ & $\begin{array}{l}\text { Working as a recreation } \\
\text { instructor } \\
\text { Teaching in the lower and } \\
\text { middle level of primary } \\
\text { school }\end{array}$ & medium \\
\hline Amela & $\begin{array}{l}\text { SFI } \\
\text { teacher } \\
\text { (former } \\
\text { mother } \\
\text { tongue } \\
\text { teacher) }\end{array}$ & $\begin{array}{l}\text { Upper secondary school } \\
\text { teacher degree }\end{array}$ & $\begin{array}{l}\text { Working as a teacher in } \\
\text { secondary school } \\
\text { Teaching a mother tongue } \\
\text { in primary school and } \\
\text { working in a bookbindery } \\
\text { in Sweden }\end{array}$ & medium \\
\hline $\begin{array}{l}\text { Anne- } \\
\text { Sofie }\end{array}$ & $\begin{array}{l}\text { SFI } \\
\text { teacher }\end{array}$ & $\begin{array}{l}\text { Teacher degree } \\
\text { Course in teaching } \\
\text { Swedish as a second } \\
\text { language }\end{array}$ & $\begin{array}{l}\text { Teaching students with } \\
\text { deficiencies in previous } \\
\text { education in intermediate } \\
\text { school } \\
\text { Teaching social studies in } \\
\text { SFI }\end{array}$ & very long \\
\hline Geedi & $\begin{array}{l}\text { Mother } \\
\text { tongue } \\
\text { language } \\
\text { teacher }\end{array}$ & $\begin{array}{l}\text { University courses in } \\
\text { social studies } \\
\text { Course in interculturality }\end{array}$ & $\begin{array}{l}\text { Working as a teacher } \\
\text { assistant in a group of } \\
\text { students speaking his } \\
\text { mother tongue and teaching } \\
\text { a mother tongue in primary } \\
\text { school }\end{array}$ & medium \\
\hline Jill & $\begin{array}{l}\text { SFI } \\
\text { teacher }\end{array}$ & $\begin{array}{l}\text { Primary school teacher } \\
\text { degree }\end{array}$ & $\begin{array}{l}\text { Teaching in the lower level } \\
\text { of primary school } \\
\text { Teaching more advanced } \\
\text { courses in SFI }\end{array}$ & medium \\
\hline Louise & $\begin{array}{l}\text { SFI } \\
\text { teacher }\end{array}$ & $\begin{array}{l}\text { Primary school teacher } \\
\text { degree }\end{array}$ & $\begin{array}{l}\text { Teaching in the lower level } \\
\text { of primary school }\end{array}$ & long \\
\hline Omaima & $\begin{array}{l}\text { Mother } \\
\text { tongue } \\
\text { teacher }\end{array}$ & $\begin{array}{l}\text { Primary school teacher } \\
\text { degree }\end{array}$ & $\begin{array}{l}\text { Teaching English as a } \\
\text { foreign language in primary } \\
\text { school }\end{array}$ & long \\
\hline Roya & $\begin{array}{l}\text { Mother } \\
\text { tongue } \\
\text { teacher }\end{array}$ & $\begin{array}{l}\text { Maths and science } \\
\text { teacher degree for } \\
\text { primary school }\end{array}$ & $\begin{array}{l}\text { Doing internship as a child } \\
\text { minder in the preschool } \\
\text { Working as a teacher of } \\
\text { newly arrived immigrant } \\
\text { children in elementary } \\
\text { school } \\
\text { Working as a language } \\
\text { instructor in preschool }\end{array}$ & medium \\
\hline Simone & $\begin{array}{l}\text { SFI } \\
\text { teacher }\end{array}$ & $\begin{array}{l}\text { Preschool teacher degree } \\
\text { Special teaching degree }\end{array}$ & $\begin{array}{l}\text { Working as a teacher in the } \\
\text { preschool and the lower } \\
\text { level of primary school }\end{array}$ & medium \\
\hline
\end{tabular}

$*$ medium $=5-10$ years, long $=10-15$ years, and very long $=15<$ years. 
The study is part of a larger project on what it means to be and become a teacher of LESLLA learners. To investigate the professional teacher identity formation, semi-structured interviews were conducted. At the beginning of each interview, the respondents were encouraged to tell the story of how they became a teacher in study track 1 and how they had learned to teach the group of LESLLA learners. This was followed up by questions for clarification and to obtain more detail on the parts that I identified as crucial for their learning. The reason I asked the teachers to "tell their stories" was to get rich qualitative data. I wanted the respondents to be free to do their own reconstruction of the process of becoming a LESLLA teacher. However, even if the teachers, in that sense, had much freedom in choosing what to tell, the interview, similarly, is viewed as a co-construction of the interviewer and the interviewee (see Kvale \& Brinkman, 2009, p. 65).

The study follows the guidelines of the Swedish Research Council (Gustafsson, Herméren, \& Pettersson, 2011). Among other things, this means that the teachers' participation was voluntary and that confidentiality is ensured since pseudonyms are used.

\subsection{Data Analysis}

The interviews were recorded and transcribed. The next step was to analyse the data thematically. Since the interviews were conducted in Swedish, the transcripts were in Swedish too. In line with thematic analysis (see Braun \& Clarke, 2006, p. 16), I started by reading the transcripts thoroughly to further familiarize myself with the data. Then, I identified and singled out the parts where the teachers reflected on their first period in the landscape of LESLLA practice. These parts were coded with the research questions as a point of departure. Relevant data were sorted into different categories and subcategories. When doing this, I made use of the Nvivo software program 10.2.1, which provided a comprehensive overview of the identified themes. In the next step, I started to look for broader themes that emerged from the coded data (see Braun \& Clarke, 2006, p. 18-20). The themes were refined several times in regard to different theoretical concepts related to situated learning in a process informed by abductive reasoning (see Jacobsson, 2010). At the end of this process, the notions of participatory practice, individual agency, negotiation and the landscape of practices, previously described in the theory section, were found to best suit the themes emerging from the data.

Even though a thematic analysis, which focuses on the learning experiences across the data, has been used, the aim has been to make each teacher visible in the findings. In this way, individual differences and not just the collective experiences can be displayed. Moreover, all participants are presented by their pseudonyms and their voices have been kept through a frequent use of examples, in terms of both summary accounts and quotations. In addition, a language close to their own has been used to better communicate the unique particularity of each case (see Kramp, 2004, p. 119).

The quotations have been translated to English. This has been a challenge since it may be difficult to catch the exact expression in another language. The goal of the translation has been to depict the teachers and their learning as truthfully as possible, based on the interviews. As a consequence, grammatical divergences have been exchanged for standard language and fillers and repeated words removed. This has been performed to avoid diverting attention from what the teachers wanted to say.

\section{Findings}

This section is divided into three main parts. First, it depicts the teachers as experienced newcomers when entering the professional LESLLA teacher field of practice. Secondly, it 
in a new landscape of practices

reviews the opportunities for learning that were afforded by the new working communities, and thirdly it deals with how the teachers responded to these opportunities.

\subsection{The Experienced Newcomer}

\subsubsection{The teachers as newcomers.}

The data reflect an anxiety about the challenges that the teachers met and/or expected to meet when they entered the teaching practice. To some, the very existence of print illiterate adults in Sweden and/or initial literacy teaching for adults was news. A particular challenge was that the teachers, when teaching emergent readers, could not in equal measure rely on print-based teaching material any longer, especially when there was a lack of a mutual oral language.

I thought that it was a bit: how will that be done? How can I? I cannot bring out a dictionary. I cannot make use of the writing technique that I had, so to speak. Instead it is about the orality. (Jill)

Another strain was the lack of adequate teaching material. Since there was not much ageadapted teaching material to use, many of the teachers had to produce it themselves. Many of them were also concerned about how to adjust the material to the learners as adults. Similarly, others worried about how they would treat the adult learners respectfully in other ways.

The mother tongue teachers, who, for the first time, were to teach Swedish with the mother tongue as a tool, articulated problems about understanding this teaching concept. One of them, Amela, told me how she was not just uncertain of how to teach like that; she could not see the point of it. When she was introduced to her first group of learners and some of them said that they did not need a teacher in their own language, which they already knew, her doubt increased. She thought: "But they're right. What are they to do with me?" This illustrates how she, at that time, was neither accepted by the teaching and learning community nor felt that she belonged there.

The anxieties that the teachers had prior to, or at the beginning of their LESLLA teaching career, were all related to the new aspects of the teaching. The examples demonstrate that the teachers were not yet familiar with the tasks, activities and functions of the teaching and learning community and that this was explicitly related to their actions and their place in the community. Simone, for example, expressed the transition from teaching in primary school to the LESLLA teaching practice with the following words:

You asked why it was difficult. Maybe it was that, that I, myself, felt secure in the other environment. It's about me . . . my work situation and my identity. There, I knew of course, I had some sort of control over it and I was skilled in what I was supposed to do.

\subsubsection{The teachers as already experienced.}

The teachers, however, did not solely picture themselves as fumbling newcomers. By explicitly referring to themselves as professionals they also appeared as confident. Roya, for instance, said that in her capacity of being a teacher, she was aware of different pedagogical strategies and was not afraid of trying new methods. In this sense, she identified herself with abilities related to the general teaching profession, rather than focusing on herself as a newcomer in the specific landscape of LESLLA teaching. In that sense, she aligned herself with a broader pedagogical framework than the field of LESLLA practices.

More commonly, the teachers drew on pre-acquired abilities and experiences, which were recognised as useful in the LESLLA teaching practice. When talking about how they felt 
in a new landscape of practices

and thought in the encounter with the new practice, the teachers referred to the fact that previously, either in compulsory school or in other study tracks of SFI, they had taught a foreign language, a second language or a mother tongue. Thus, they had all come across a teaching context that to some extent resembled LESLLA. They had already taught the subject, i.e. they had taught initial literacy for children in an L1 setting, language and/or had given remedial instruction to children with reading and writing disabilities. The teachers who had worked with initial literacy teaching for children, stated, for example, that they could adopt formerly used teaching techniques and ideas of how to structure the material (even if these materials had to be adjusted to the new group of learners). The SFI teachers with a primary school background said they were already familiar with characteristics of the LESLLA learner, that they were used to teaching immigrants, or had met semi-literate parents of their primary school students.

Even though the teachers, most frequently, considered their former teaching experiences and abilities as guiding principles, some referred to other types of experiences as well. From the encounter with an SFI teacher with a negative and stereotypical view of immigrants, who she had met as a student herself, Omaima learned to be careful about expressing prejudicial opinions of the learners and their lives. "I avoid many attitudes in the classroom because I know how the students or participants feel when they see a teacher doing this and saying this, because I was in their shoes." Consequently, the teachers did not solely situate prior abilities (see Hodkinson et al., 2004) by drawing on knowledge or adapting a teaching technique acquired in another teaching community, but by using their feelings to identify with the learners. The example also illustrates how the personal sphere of the teachers' life, not just the work-related experiences, interplayed with their professional identity formation.

\subsection{Opportunities to Learn Afforded by the Working Community}

The professional identity formation of the teachers was, above all, enabled by opportunities to learn the specific features of LESLLA teaching practice afforded by the working communities. In short, these opportunities can be categorised as organised and non-organised.

\subsubsection{Organised learning opportunities.}

To some extent, the opportunities for participation were based on organised activities that served to help newcomers orient themselves in the new practice. Most teachers brought up the opportunity to observe more experienced colleagues and/or teach together with them before getting their own classes.

Here, in the work team, I was to work alongside a colleague for a week, so that I could see a little. . . . I followed Erika. She was my mentor. Yes, it was so relieving to get the opportunity to work beside someone and to see what she did. "Aha, that's right. You can do it that way", and to get tips about teaching aids. (Simone)

The quotation reflects the significance of getting access to the practice by observing how an already initiated colleague, an old-timer, acted, and then collaborating with her/him. In that way, the teachers learned about the artefacts, the methods and materials used in this type of teaching.

The observations could also give the teacher an idea of how to relate to the learners:

When I started to work I first practiced with Maria and saw her approach. . . . I learned much from her, actually, when it comes to patience, when it comes to repetition, when it comes to teachers' attitude towards adults. There are many steps to being able to teach adult illiterates. To teach adults, that is one thing. To teach 
in a new landscape of practices

illiterates and adults, that is another thing. To work with adults, you may need to be patient or respectful and to listen. But with illiterates, you need twice as much patience and must be twice as respectful because they are very sensitive, very sensitive. (Omaima)

Here, the emphasis is on the learners as adults and emergent readers simultaneously, and on the importance of balancing these perspectives when approaching the learners. The new LESLLA teacher could, in this sense, learn what values were part of the teaching practice.

Another type of organised support was supervision. Amela told me how she and the other mother tongue teachers, at the beginning of their LESLLA teaching career, received explicit guidance from one of the SFI teachers. This, she thought was a condition for the close cooperation between the SFI teachers and mother tongue teachers, which came to enable them to expand from a small project to a much-coveted school. Her conclusion shows how the relations to the colleagues were central in the identity formation. The supervision did not just contribute to a single teacher's development; it also contributed to affinity between different types of members of the community.

Two of the teachers did not speak of an immediate support from their schools at the beginning of their LESLLA teaching career. This may have been because they started to work at a time when LESLLA learners were to be incorporated in the SFI education and so there was a less elaborate teaching practice within the organisation. Louise said about her first period:

But I did a rather poor job then, I feel, in comparison with what I do today. But it was what I could and this class had a very low status here, and there was only one initial literacy class here then and it was a bit like the one who was the latest person to be employed was the one to teach it ... There was no-one who was passionate about it and no-one who spoke for the learners.

The quote reflects a lack of support from the school community, visible in how this type of learner and teaching practice were (dis)regarded and non-prioritized. In this setting and without fellow colleagues that could have made up a mutual practice, Louise thought that she did not learn much.

\subsubsection{Non-organised learning opportunities.}

It was not only the organised supporting opportunities that seem to have played a part for the teachers in the new teaching practice. When beginning her work as a LESLLA teacher, Simone was not sure if she would be well received by her new colleagues. Due to an extensive turnover of the staff in the municipality school system, 16 unqualified teachers at the SFI had to leave and make room for her and 15 others. "It wasn't a fun situation. One felt that one, I, had pushed out someone else. But in spite of that it was a good atmosphere here and we were very well received." The fact that Simone brought this up as something that worried her, illustrates the importance of feeling welcomed. Ann-Sofie, too, highlighted this. In spite of her position as a well-qualified LESLLA teacher, she felt uncomfortable when she, as a newcomer to a school famous for its mother tongue-based teaching, was to be the teamleader for well-experienced LESLLA teachers. She was reassured, however, when a colleague suggested that the members of the team were to be resources for each other. "Then I didn't need to be someone "who knows"; instead I could ask the others all the time what they knew and we could help each other". The example sheds light on two things: firstly, that every local teacher community has its unique type of practice in spite of similarities across the LESLLA teaching settings in SFI, and secondly, that the formation of the LESLLA teacher 
identity does not just happen when they are new to this field of teaching, but also when they journey on to a new type of teaching community within the landscape.

An example of the opportunity to learn from more experienced colleagues can be seen in Geedi's encounter with the new practice. Geedi came from a society where it was very important to show respect to older people. When starting to teach LESLLA learners, he found that he sometimes had to rebuke those who were older than him. In the following quotation, he refers to the dilemma of handling a talkative student:

She is 55 years old, and I may know her son, and I've got to be professional, but at the same time I've got to show respect. And she does things that are not beneficial for the learning in the classroom. That is difficult. What can I do to handle it? But I always got support from Amela, who works here, so I used to bring it up with her and then I got ideas about how to handle the situation. There were many private conversations to handle it instead of bringing it up in front of the class.

As the quote shows, his colleague played an important role in helping him to negotiate the LESLLA teacher identity in relation to another of his identities. This led to the new action of correcting the student in private.

The way of organising by which more than one teacher had responsibility for a class was formally structured. Nonetheless, this gave the opportunity to more spontaneous teacher conversations and mutual support "that implies that one shares both experiences and good and bad days" ... a and then finds material (Simone). Likewise, the teaching and learning practice provided many opportunities for the teachers to learn as a side effect of the teachers' official mission to facilitate the learning of their students. From their interactions with the learners, teachers developed their understanding of the students' learning strategies, of what it meant to be oral literate (rather than print literate), and what methods and material would be suitable. The impact of these new perspectives is described in how teachers came to work with the material in a way that they had not done previously; by peeling off everything that might divert the focus from the main message of the text, and/or by taking photos of the outdoor environment, e.g. signs, and bringing these to the classroom. Moreover, in the case of Amela, the continuing response from the students made her realise the benefits of mother tongue-based teaching. The students turned from being critical towards having a Bosnianspeaking teacher, to being positive about it. They came to see that it helped them to understand Swedish better.

\subsection{Responses to the Opportunities to Learn}

The teachers reflected on how they both responded to the different opportunities for learning in a purposeful way and participated in learning activities less consciously. Moreover, different working communities seemed to have different importance for the teachers, and their strategies of learning to teach LESLLA learners entailed both general and individual features.

\subsubsection{Purposeful and less purposeful participation in the learning opportunities.}

The teachers' responses to learning opportunities were often described as an individual attempt to develop. Omaima, for instance, said about the observations of a colleague's teaching:

I was with her in many, many / many lessons and I saw her methods even though I had brought my own (teaching experiences) from my native country. But I thought that I needed to see how she taught, and I was to teach a language that I was still learning myself. 
in a new landscape of practices

Even though Omaima, as she stated, was already an experienced teacher, she found the need for new input from her colleague. By trying to fill this need, she exercised individual agency. Like most of the teachers, she did this to understand the new practice. But a more personal motive emerged too. She felt that she did not know much Swedish, a language she was to teach for the first time, and by getting an idea of how to teach, she could feel confident in spite of that. In that sense, Omaima's unique history influenced how she engaged with the opportunity to observe her colleague. The example illustrates how the teachers' professional identity formation was enabled trough a purposeful negotiation of old and new experiences.

The process of adjusting old teaching experiences to the new practice was not always consciously made, however. Roya said that during her first year she used a lot of pictures and let her students sing about weekdays etc. She was used to such methods from working with preschool children. But when looking back, she could see that she had abandoned this type of teaching even though she did not know why. "It has just disappeared by itself. . . one gains new experiences that are more relevant and adjusted to adults." In this case, just by being a part of the LESLLA teacher practices, Roya came to change her teaching actions so that they became more in line with the contemporary teaching community.

\subsubsection{Taking learning opportunities within and outside the school communities.}

The teachers participated in multiple communities: e.g. the teaching and learning community, the work team community and the general school community. But the roles of these working communities as opportunities for learning were emphasized differently by research participants. Whereas, some mentioned particular colleagues who, either through an organised or a non-organised learning opportunity, had meant a lot for their negotiation of the new teaching and learning practice, others tended to speak more about how they learned from taking actions in the teaching and learning community. It was also significant how AnneSofie and Louise, who had received less support from their school and teacher community, actively reached out for other sources of knowledge, such as books or experts. For Louise, a training opportunity with literacy pedagogues became of great importance. She described this training as an eye-opener, as, for the first time, she grasped that there was a particular technique for initial literacy learning and teaching for adult learners in an L2 context. Someone had put it into words. Then, she also learned why and how to drum the sounds of the consonants into the heads of the students and to visually stage how sounds represented by letters could be combined. Still, more than 10 years later, she made use of a teaching technique reflecting this. Moreover, she realised something about her profession: "It was not just that I wanted to work with immigrant students, I also wanted to work in LESLLA teaching".

However, it was not only the teachers who lacked learning opportunities organised by the school who sought opportunities to learn on their own initiative. For example, some had studied or planned to study the university course of Swedish as a second language after beginning their LESLLA teacher career. Furthermore, Geedi stated that he actively turned to books to learn more about pedagogy, for example after having attended an in-service training with experts. He said:

You develop if you wish to develop. Consequently, one can be a person who works, but does not have a genuine interest in the subject. Then one can't develop more than from what one experiences in the school. But on the other hand, one can develop from having a wider understanding of what one is doing. Then you can look for knowledge where it is available. 
In this quote, Geedi pictures himself as a person who, in contrast to others, actively seeks to learn more about what he is involved in. Even though his school provided supporting structures for learning, it was not enough. From his personal values on learning and work, possibly related to the fact that from having attended many university courses, he was used to studying, Geedi came to respond to the opportunities afforded by the school by enhancing the study of the topic that the school provided.

The examples of Geedi on the one hand, and Anne-Sofie and Louise on the other, indicate that teachers may reach for external communities either if the one provided by the working communities is not sufficient, or because such a way of learning is part of how they define themselves professionally.

\subsubsection{Collective and individual ways to learn.}

The teachers' learning process had some general characteristics even if the kind of actions that the teachers took was imprinted by their previous biography. An example is seen in a story Anne-Sofie told:

In that group, there was a woman who said that she as a child had dreamt of going to school. But as she couldn't, she had invented her own alphabet. So, she could read and write in her own language. She had the Bosnian words, but wrote them with her own letters and it was kind of a challenge for me to understand what sound corresponded to what sign for her. So, I had to learn a little to read and write in her (print) language and the first time I wrote the word 'door' in her language beside the picture of the door and she could read her own word, then she became so happy. It was like she opened up, because she had understood that this language was not something that someone else could read. But then she saw: "What! I can write so that someone else can read what I have written." It was so exciting to see how this longing for learning to read and write is so strong that one even can create one's own (written) language if one does not get access to the official one.

Here, Anne-Sofie first listened to the student's personal history. Thus, she discovered something more than a single student's dream - she learned about the driving force behind literacy acquisition, which is significant knowledge for a LESLLA teacher. Secondly, this inspired her to take a new action for the benefit of the student's learning - to learn to read in the student's own language. This speaks of a collective and individual way to learn at the same time. The different steps of the process - to listen and/or observe and take a new action based on that - represented a pattern that occurred in most teachers' processes. But the particular approach of responding to the learner's need was an individual, unique act, which is in line with the teacher's professional biography. From the beginning of her teacher career, Anne-Sofie had been used to listening to the life stories of her students and to see their learning experiences as a basis for teaching. Moreover, she had already learned to speak Bosnian to facilitate the learning for the large group of Bosnian students she taught. This made the process of learning the specific alphabet of this particular Bosnian student easier.

\section{Discussion and conclusion}

The aim of this study was to explore how the professional identity of already experienced teachers is formed when they begin to work in the LESLLA field of practice. Viewing the interview as situated in both time and space, and as co-constructions of the respondent and the interviewer, the accounts are subjective and fluid. Moreover, the results are my interpretation of how the teachers interpreted their professional development. Nevertheless, the ontological 
in a new landscape of practices

assumption is that the teachers' stories, as well as being the teachers' self-presentations, simultaneously reflect actual experiences of the teachers, and the findings suggest three central features in the new LESLLA teachers' identity process.

\subsection{Transforming of the Professional Identity}

The LESLLA teachers' professional identity is not formed from scratch. Instead of viewing this process as a formation of a new teacher identity, it is rather a question of transforming an already existing professional identity. Previous research brings up critical periods of teachers' learning, e.g. when new teachers begin to teach, or times of reform (see Avalos, 2011, p. 11; Vähäsantanen \& Eteläpelto, 2009). This study highlights another less researched critical period - the transfer to one teaching landscape of practices to another. In this transition, the teachers make use of their prior identity, formed in both professional and personal spheres, by situating old abilities and experiences in the new landscape. This implies that the teachers, early in their new career, recognise that some aspects of their previous way of teaching are valid whereas others are not. For example, since the learners are not print literate, the teachers cannot rely on print material any longer, although they can apply methods of initial literacy teaching in an L1 setting.

That many teachers in the study bring up teaching of initial literacy in L1 as a valid ability and experience may, at first sight, be linked to the fact that teachers new to the field of adult education tend to concentrate on the methods of teaching (Andersson et al., 2013). From that, an interpretation may be that teachers in a new teaching practice look for something concrete and are mainly concerned with their own actions. However, the data, simultaneously, reflects a focus on the learners; e.g. in terms of adjusting the teaching and learning material to them, listening to their learning experiences and recalling what had been required when dealing with people with similar needs. Thus, it may be more appropriate to assume that teachers in a new landscape of practices, rather than clinging on to tried and tested methods, make use of any piece of reference they have. Since none of the teachers in the study had previously met adults who were emergent readers, at least not in a teaching and learning situation, they reached out for experiences that, in one way or another, reminded them of the LESLLA learners and teaching. Hence, the professional experiences and abilities, in some cases, were completed with experiences from the personal sphere.

\subsection{Diversity and Unity in What Different Communities Mean for Learning}

The frequent examples of how the teachers draw on their previous experiences and abilities, do not solely refer to a negotiation of what is valid or not. Possibly, these are also an account of how the teachers' individual history influences the outlook on the learning opportunities. In line with Billett (2004), the study reflects a participatory practice, where the teachers' personal biography is part of how they negotiate the opportunities to learn. However, what this study particularly shows, is how, for some teachers, the emphasis on their former abilities and experiences is stronger, whereas other teachers stress the support from the new communities.

Moreover, the teachers tend to accentuate some of these new communities more than others. Of all the practices in the professional landscape, the teaching practice seems to be of particular importance. It is a practice which all teachers have access to and in which they come to develop their understanding and activities of LESLLA teaching. Also, it is the practice which all other practices support - a centre of the landscape of practices. This can be related to what Hökkä et al. (2008, p. 60) find, that teachers belong to many work-related communities and that the teaching is central for their professional identity. But whereas the teachers in that study, primarily due to the organisation of their workplace, learned in regard to their subject matter communities, this study reflects a diversity in the role that practices 
other than teaching play for the teachers' learning. In part, the significance of a certain community seems to depend on the lack of learning opportunities afforded in others - if few opportunities exist, it is likely that the ones afforded will be more important. But even when there are learning opportunities, e.g. provided by the work team community, and whether they are organised or non-organised, the teachers do not value these or make use of them equally. This can be understood from the notion of individual agency; that one's actions should be in line with one's identity (see Buchanan, 2015). Due to the teachers' biographies, they tend to act in different ways, even if similar opportunities are afforded.

It is also significant to see how part of the teachers' professional identify relates to practices they are not physically participating in. Such imagination (see Wenger-Trayner \& Wenger-Trayner, 2015, p. 21) may for instance be seen in how teachers refer to themselves as teachers in general rather than LESLLA teachers specifically, or portray themselves as LESLLA teachers even when there is no LESLLA teacher community at the school.

\subsection{Both Organised and Non-Organised Learning Opportunities are Vital}

The learning opportunities afforded by the occupational landscape of practice play a crucial part in the teachers' identity transformation. Not only do they help the teachers to develop their understanding of the tasks, activities and functions (see Lave \& Wenger, 1991) of the LESLLA teaching community, they also enable the teachers to cooperate. Such cooperation is seen both within a certain practice e.g. when it comes to the mutual lesson planning of teacher colleagues, and across the boundaries of the different teacher communities, like the mother tongue teachers' and SFI teachers' communities.

Together, the organised and non-organised learning opportunities enable the development of common values and approaches in LESLLA teaching, something which, in turn, helps to develop a collective identity. More specifically, the organised opportunities serve to legitimate the LESLLA teaching and learning practice as a whole, acknowledging that, to carry out the job as a LESLLA teacher, one needs to learn about the specific conditions of the practice. Also, they give the new teacher access to old-timers' ways of doing things and make it legitimate for the newcomer to participate peripherally (see Lave \& Wenger, 1991). In parallel, the non-organised learning opportunities of the day-to-day advice and the possibilities to exchange ideas with colleagues provide a forum for the teachers to reflect together on their teaching. There is a fine line between these two types of opportunities, though. The ways of organising the teachers and classes can provide opportunities for learning even if that is not the purpose, and an in-service training arranged by the school may lead to a teacher actively continuing to learn about LESLLA teaching.

\subsection{Conclusion}

This study focuses on the learning process of teachers who transfer to another type of teaching practice. Building on former studies of teachers' professional identity (e.g. Beauchamp \& Thomas, 2009; Rappel; 2015) the data implies that the teachers' professional identity transformation is a matter of individual agency as well as of contextual factors. This means that teachers tend to identify more strongly with some working communities than others, and respond differently to the learning opportunities these offer.

The study highlights that even experienced teachers who begin a teaching career in a new field are in need of learning opportunities at work. Although new LESLLA teachers can recognise the usefulness of their previous experiences and abilities and situate them in the new landscape of practices they participate in, they may face many challenges due to their unfamiliarity with the particularity of the new teaching practice. To help the teachers understand LESLLA teaching and improve their ability to act in accordance with it, schools should better ensure that there are opportunities for the teachers to learn. As what the study 
has shown, support can be afforded in different ways and communities. Organised learning opportunities contribute to the legitimation of the LESLLA teacher profession and organisational structures may also enhance the possibilities for non-organised support. As a consequence, it is advisable for a school to afford a diversity of opportunities for learning: e.g. to provide opportunities for teachers to reflect on their previous professional and personal experiences in relation to the LESLLA teaching practice, to let them participate in teaching activities with more experienced colleagues, and to help teachers to take part of learning activities outside the school communities.

This paper has concentrated on teachers who, in spite of their teaching experience, are new to the landscape of LESLLA teaching. Therefore, it does not say much about how experienced LESLLA teachers continue to transform their identity. Neither does it focus on how formal education on LESLLA-related issues may play a part in the teachers' understanding of the teaching practice or their feelings of belonging to it. Such questions are saved for future research to deal with. Of interest for future research is also to further explore the phenomenon of teacher's professional identity in the transition from one occupational landscape to another. What can be understood about e.g. the collective teacher identity formation that occurs in such a process?

\section{References}

Andersson, P., Köpsén, S., Larson, A., \& Milana, M. (2013). Qualification paths of adult educators in Denmark and Sweden. Studies in Continuing Education, 35(1), 102-118. doi: 10.1080/0158037X.2012.712036

Avalos, B. (2011). Teacher professional development in Teaching and Teacher Education over ten years. Teaching and Teacher Education, 27, 10-20. doi:

10.1016/jtate.2010.08.007

Beauchamp, C., \& Thomas, L. (2009, June). Understanding teacher identity: An overview of issues in the literature and implications for teacher education. Cambridge Journal of Education, 39(2), 175-189. doi: 10.1080/03057640902902252

Beijaard, D., Meijer, P., \& Verloop, N. (2004). Reconsidering research on teachers' professional identity. Teaching and Teacher Education, 20, 107-128. doi: 10.1016/j.tate.2003.07.001

Bigelow, M., \& Vinogradov, P. (2011). Teaching adult second language learners who are emergent readers. Annual Review of Applied Linguistics, 31, 120-136. doi: $10.1017 / \mathrm{S} 0267190511000109$

Billett, S. (2004). Learning through work: Workplace participatory practices. In H. Rainbird, A. Fuller, \& A. Munro (Eds.), Workplace learning in context (pp. 109-125). London, UK: Routledge.

Billett, S. (2006). Relational interdependence between social and individual agency in work and working life. Mind, Culture and Activity, 13(1), 53-69.

Braun, V., \& Clarke, V. (2006). Using thematic analysis in psychology. Qualitative Research in Psychology, 3(2), 77-101. doi: 10.1191/1478088706qp063oa

Buchanan, R. (2015). Teacher identity and agency in an era of accountability. Teacher and Teaching, 21(6), 700-719. doi: 10.1080/13540602.2015.1044329

Eteläpelto, A. (2008). Perspectives, prospects and progress in work-related learning. In S. Billett, C. Harteis, \& A. Eteläpelto (Eds.), Emerging perspectives of workplace learning (pp. 233-247). Rotterdam, Netherlands: Sense Publisher.

Farrelly, R. E. (2012). Emerging from the echo chamber: An activity theory perspective on L2 teachers on adult emergent readers. Department of Linguistics. Salt Lake City, USA: University of Utah. 
THE EXPERIENCED NEWCOMER: the (trans)forming of professional teacher identity

in a new landscape of practices

Fuller, A., Hodkinson, H., Hodkinson, P., \& Unwin, L. (2005). Learning as peripheral participation in communities of practice: A reassessment of key concepts in workplace learning. British Educational Research Journal, 31(1), 49-68. doi: 10.1080/0141192052000310029

Gustafsson, B., Herméren, G., \& Pettersson, B. (2011). God forskningssed. Retrieved on 1 June, 2014, from https://publikationer.vr.se/produkt/god-forskningssed/

Hökkä, P., Rasku-Puttonen, H., \& Eteläpelto, A. (2008). Teacher educators' workplace learning: The interdependency between individual agency and social context. In S. Billett, \& C. Harteis (Eds.), Emerging perspectives of workplace learning (pp. 51-65). Rotterdam, Netherlands: Sense Publishers.

Handley, K., Sturdy, A., Fincham, R., \& Clark, T. (2006, May). Within and beyond communities of practice: Making sense of learning through participation, identity and practice. Journal of Management Studies, 43(3), 641-653.

Hodkinson, P., Hodkinson, H., Evans, K., Kersh, N., Fuller, A., Unwin, L., \& Senker, P. (2004). The significance of individual biography in workplace learning. Studies in the Education of Adults, 36(1), 6-24.

Jacobsson, G. (2010) Abduktion - en forskningsmetod för psykodynamiska terapeuter. Matrix, 27 (4), 324-347.

Kramp, M. (2004). Exploring life and experience through narrative inquiry. In K. B. deMarrais, \& S. D. Lapan (Eds.), Foundations for research: Methods of inquiry in education and the social sciences (pp. 103-124). London, UK: Lawrence Erlbaum Associates Publisher.

Kvale, S., \& Brinkmann, S. (2009). Den kvalitativa forskningsintervjun. Lund, Sweden: Studentlitteratur.

Lave, J., \& Wenger, E. (1991). Situated learning: Legitimate peripheral participation. Cambridge, UK: Cambridge University Press.

Liu, Y., \& Xu, Y. (2013). The trajectory of learning in a teacher community of practice: a narrative inquiry of a language teacher's identity in the workplace. Research Papers in Education, 28(2), 176-195. doi: 10.1080/02671522.2011.610899

Magro, K. (2008). Exploring the experiences and challenges of adults from war-affected backgrounds: New directions for literacy educators. Adult Basic Education and Literacy Journal, 2(1), 24-33.

Nyström, S. (2009). Becoming a professional. Linköping, Sweden: Linköping University.

Rappel, L. J. (2015). Integrating the personal and the professional: Marking the career paths of adult language educators. Adult Education Quarterly, 65(4), 313-325. doi: $10.1177 / 0741713615585573$

Shelley, M., Murphy, L., \& White, C. (2013). Language teacher development in a narrative frame: The transition from classroom to distance. System, 41, 560-574. doi: 10.1016/j.system.2013.06.002

The Swedish National Agency for Education. (2012). Utbildning i svenska för invandrare: Kursplan och kommentarer. Stockholm, Sweden: Skolverket.

The Swedish National Agency of Education. (2017). SFI - personal - riksnivå. Retrieved on 1 June, 2017, from https://www.skolverket.se/statistik-ochutvardering/statistik-i-tabeller/utbildning-i-svenska-for-invandrare/elever-ochkursdeltagare/elever-och-kursdeltagare-i-kommunal-vuxenutbildning-i-sfi-ar-2016$\underline{1.261665}$

Vinogradov, P. (2013) Defining the LESLLA Teachers Knowledge Base. In T. TammelinLaine, L. Nieminen, \& M Martin (Eds.), Low-educated, second language and literacy acquisition - Proceedings of the $8^{\text {th }}$ Symposium (pp 9-24) Jyväskylä: University of Jyväskylä. 
THE EXPERIENCED NEWCOMER: the (trans)forming of professional teacher identity

in a new landscape of practices

Vähäsantanen, K., \& Eteläpelto , A. (2009). Vocational teachers in the face of a major educational reform: Individual ways of negotiating professional identities. Journal of Education and Work, 22(1), 15-33. doi:10.1080/13639080802709620

Vähäsantanen, K., \& Billett, S. (2008). Negotiating professional identity. In S. Billett, C. Harteis, \& A. Etheläpelto (Eds.), Emerging perspectives of workplace learning (pp. 3549). Rotterdam, Netherlands: Sense Publishers.

Wenger-Trayner, E., \& Wenger-Trayner, B. (2015). Theory. In E. Wenger-Trayner, M. Fenton O'Creevy, S. Hutchinson, C. Kubiak, \& B. Wenger-Trayner (Eds.), Learning in landscapes of practices (pp. 13-29). Oxon, UK: Routledge.

Widin, J., Yasukawa, K., \& Chodkiewicz, A. (2012). Teaching practice in the making: shaping and reshaping the field of adult language, literacy and numeracy teaching. Australian Journal of Adult Learning, 52(1), 9-38. 